\title{
Developing a water strategy for sustainable irrigated agriculture in Mediterranean island communities - Insights from Malta
}

\author{
Lamprini Papadimitriou ${ }^{1}$, Daniela D’Agostino ${ }^{2}$, Malcolm Borg ${ }^{3}$, Stephen Hallett ${ }^{1}$, Ruben Sakrabani ${ }^{1}$, \\ Andrew Thompson ${ }^{1}$, Jerry Knox ${ }^{1}$ \\ ${ }^{I}$ School of Water, Energy and Environment, Cranfield University, Cranfield, United Kingdom \\ ${ }^{2}$ Department of Land and Water Resources Management, CIHEAM Mediterranean Agronomic Institute of Bari, Valenzano, \\ Apulia, Italy \\ ${ }^{3}$ Malta College of Arts, Science and Technology (MCAST), Paola, Malta \\ Corresponding author: \\ Jerry Knox, Cranfield University, Cranfield, Bedford MK43 0AL, UK. \\ Email: j.knox@cranfield.ac.uk
}

\begin{abstract}
The future sustainability of irrigated agriculture in Mediterranean island communities faces a raft of economic, environmental and socio-economic challenges. Many of these are inextricably linked to the extreme levels of water scarcity that exist in the region. With a focus on Malta, we developed a water strategy to identify the priorities for action to support decision makers, practitioners and the agrifood industry in achieving agricultural and water resources sustainability. The methodology involved a combination of evidence synthesis, to inform the development of a Drivers-Pressures-State-ImpactResponse (DPSIR) framework. These priorities were then used to define a set of key actions under three thematic pillars of sustainability (environment, economy and society). Our analysis confirmed that irrigated agriculture in Malta is not only impacted by environmental factors such as the challenging climate and geography of the region, but is also strongly influenced by a range of economic (tourism development, European Union accession) and societal (population growth, environmental regulation) drivers of change. The developed strategy is underpinned by priority actions relating to improved water and soil management. The reduction of water and energy footprints in crop production, the establishment of demonstration farms and the support of policies that promote "value adding" activities are examples of key priority actions for the environmental, economic and societal pillar respectively. Regarding the scale of intervention, the analysis distinguishes research as being important for supporting many of the economy-focused actions.
\end{abstract}

Keywords: abstraction; groundwater; policy, soil; water resources

\section{Introduction}

For many countries in the Mediterranean region, the problem of water scarcity poses a major waterrelated risk to agriculture (MESDC, 2018). Water scarcity is the combined output of low average precipitation and significant annual and inter-annual variability, in areas of increasing water demand (Aparicio et al., 2019), leading to regular supply-demand imbalances. The Mediterranean islands are particularly vulnerable to water-related risks given that groundwater is the dominant resource and the small size of islands constrains formation of surface water bodies (MRA, 2013; Aparicio et al., 2019).

Agriculture is the primary sector in terms of land use and water consumption in most Mediterranean islands (Viola et al., 2014). However, a lack of precipitation and high evapotranspiration (ET) rates during the summer correspond to the period of maximum crop growth and development. Thus, agricultural water demands mostly relate to irrigation, which is essential to support production of high quality crops in the region. Groundwater is the dominant "blue" water source for most Mediterranean islands and critical for supporting local irrigated agriculture (Aparicio et al., 2019). However, this resource is generally over-exploited in terms of quantity, while its quality is deteriorating due to saline intrusion and nitrate pollution (Viola et al., 2014; Aparicio et al., 2019). Under these conditions, strategic management is essential to secure the future sustainability of water resources and the development of the agricultural sector in Mediterranean islands (MESDC, 2018). 
In this paper we develop a strategy to support agricultural and water resources sustainability using Malta as a reference case, given that it is the Mediterranean island with the highest degree of water scarcity and highest population density (MRA, 2013); it thus makes an interesting "extreme" exemplar in terms of water resource pressures. The strategy focuses on irrigated food crop production and "blue" water, which is often limited in supply, has competing demands and a high opportunity cost. Dryland or rainfed crops were excluded. The strategy was developed taking into account the existing regulatory frameworks relevant to the agricultural sector in Malta. The objectives underpinning the research were to assess current challenges and constraints in managing water resources in irrigated agriculture and to propose a suite of actions that could be implemented to mitigate the emerging water risks the sector faces to support sustainable agricultural development on the island.

\section{Water use, risks and challenges}

With about $25 \times 10^{6} \mathrm{~m}^{3}$ available freshwater resources per year and a population of approximately 434,000 (United Nations, 2017), Malta ranks highest in the list of European countries most heavily affected by water scarcity, and in the top ten most water-stressed countries globally (MBB, 2014). Malta has virtually no surface water resources to manage, meaning that irrigation needs are met almost exclusively by groundwater (MEPA, 2011). Agriculture is now the primary consumer of groundwater on the island (National Statistics Office, 2015) with abstraction rates continuing to rise beyond sustainable levels. It is notable that between 2005 and 2013 groundwater abstraction showed an underlying trend of $+4 \%$ per year (National Statistics Office, 2015). Considering other sectors which also compete for water, agriculture remains the largest sector, responsible for nearly half $(46.7 \%)$ of all freshwater consumption between 2005 and 2013, followed by household demand (36.2\%) (National Statistics Office, 2015). According to the FAO (2006), the estimated annual agricultural irrigation demand in Malta is $\sim 15 \times 10^{6} \mathrm{~m}^{3}$. However, according to Eurostat (2012), a much larger volume $\left(28.2 \times 10^{6} \mathrm{~m}^{3}\right.$, equivalent to $c 10,000 \mathrm{~m}^{3}$ per hectare) was used for irrigation in 2010 . There remains ongoing debate regarding the actual volumes of water used for irrigation, in terms of both theoretical demand and actual abstraction.

Over a third (36.2\%) or 11,450 ha of Malta is classified as agricultural land (Eurostat, 2012), of which $30 \%$ is irrigated (MEPA, 2011). The total agricultural area in Malta is heavily fragmented and as a result, the average size of agricultural holdings is only 0.9 ha, one of the smallest in the EU27 (Eurostat, 2012). Over half the arable area (58.5\%) is used for the cultivation of forage crops (notably wheat). The rest is used for cultivation of vegetables (23.9\%), potatoes $(8.9 \%)$, flowers and seeds $(0.3 \%)$ (MEPA, 2011). In terms of production and economic output, potatoes are the most economically important cash crop, with spring potatoes grown exclusively for export, mainly to the Netherlands, Switzerland, Germany and the UK and with winter potatoes grown for local markets (MESDC, 2018). Most of Malta's agricultural output is grown to meet local demand and exports represent only a very small proportion of total output (2.6\%) (MESDC, 2018). Due to its typical semiarid Mediterranean climate, Maltese agriculture is heavily reliant on irrigation, especially for summer cropping. The crops that depend most on irrigation are potatoes (23\% of irrigated area), vineyards $(15 \%)$ and fruit and berry plantations (8\%) (National Statistics Office, 2016).

\section{Water demand and value of irrigated agriculture}

Agriculture contributes 1.9\% to Malta's gross domestic product (MEPA, 2011), equating to approximately 152 million Euros. Although this is a small percentage in economic terms, the value for the sector is nevertheless significant for reasons that do not relate directly to economic measures. For example, it provides a multi-functional role including supporting rural livelihoods for many familyowned farms, underpinning food production and food security on the island, conserving culinary culture and traditions, enhancing land and environmental protection, contributing to natural landscape preservation as well as supporting tourism, mainly through the provision of fresh fruit and vegetables and local produce (Roberts et al., 2015; Friends of the Earth, 2017; MESDC, 2018).

Over the last three decades, there has been a notable shift towards irrigated agriculture in Malta, driven mostly by unregulated, extensive groundwater abstraction (MESDC, 2018). From a historical context, this shift related to changes in land use that occurred between the 1950s and 1980s, following the 
boom in tourism development and consequent demand for new housing, infrastructure and road construction. During this period, the pattern of land use changed radically, with the area dedicated to agriculture reducing and increasingly being abandoned, whilst urban areas expanded steadily. Meanwhile, there were also considerable changes in farming techniques and land management. The traditional dryland cultivation methods, mostly producing fodder crops, were abandoned in favour of more profitable high-value irrigated crops (Charlton and Beeley, 1987). The increased profits associated with irrigated agriculture (on average 3.5 times higher than dryland cultivation) strengthened the incentive for a transition to irrigated production (Attard and Azzopardi, 2005). This was particularly for potatoes which are now Malta's main export crop; the net profit from irrigated cultivations are reported to exceed that of an equivalent area of rainfed forage wheat by a factor of 20 (Attard and Azzopardi, 2005). A summary of the main irrigated crops together with indicative estimates of the volumes of water used for irrigation and value is given in Table 1. Although the figures should be interpreted with caution, they highlight the importance of potatoes, vegetables and vineyards in terms of irrigation demand and output (value) to the island economy.

The significance of irrigation for quality assurance has also become particularly important since Malta's accession into the EU, which required its agriculture to become more profitable in a highly competitive and open market. Assurance of appropriate quality of water for irrigation was also vital for economic competitiveness, to support products of higher quality and monetary output such as floriculture and organic agriculture (Attard and Azzopardi, 2005).

\section{Water-related risks}

The main physical risk has been the lack of adequate water resources to support agriculture (MESDC, 2018), but apart from quantity, the sector also faces major water quality risks. Groundwater quality is reported to be deteriorating, mainly due to nitrate leaching, to the extent that it will soon be unsuitable for irrigation, exceeding permissible nitrate levels. Excluding aquifer recharge, the levels of water abstraction are reportedly $50 \%$ higher than required levels for sustainable management. Continuing groundwater abstractions therefore risk increasing the problem of aquifer contamination, and risks associated with reducing the quality of the remaining groundwater resources (MBB, 2014). Another threat impacting on groundwater resources is saline intrusion. Groundwater quality has deteriorated to such levels that there are implications for its suitability for irrigation (Eslamian and Eslamian, 2017), as irrigation with brackish water can have major implications for the quality and quantity of agricultural yields and in the longer term could have detrimental effects on the quality and sustainability of agricultural soils (Daliakopoulos et al., 2016).

Climate change is also expected to exacerbate the water-related risks in Malta. Climate projections for the region for the end of the $21^{\text {st }}$ century show precipitation decreases of between $-5 \%$ and $-15 \%$ and between $-20 \%$ to more than $-25 \%$ (Jacob et al., 2014) for the stabilization and high-end climate (RCP4.5 and RCP8.5) scenarios (van Vuuren et al., 2011), and a concentration of rainfall to fewer higher intensity events (Jacob et al., 2014; Vautard et al., 2014; Eslamian and Eslamian, 2017). These new climate patterns are expected to further compound water availability issues, as runoff into the sea will increase under higher intensity events, at the expense of infiltration and groundwater recharge, thus impacting on the sustainable recharge of groundwater resources (MBB, 2014). For agriculture, climate change is expected to impact directly across the Mediterranean region, causing decreases in crop yield, increased risks of crop failure and increases in irrigation demand. Growing seasons are expected to shorten whilst plant heat stress during vital periods of crop development will increase. Moreover, the higher intensity rainfall events during the sowing period may also increase the risks linked to soil erosion and flash flooding (Zdruli, 2014).

\section{Challenges facing Maltese agriculture}

For Maltese agriculture, there are a number of important factors relating to physical, structural, operational, economic, regulatory and social characteristics that challenge and/or constrain the potential for the sector to expand and develop in a sustainable manner. The main physical limitation is the small geographical size of the island combined with the high population density, a situation that results in agricultural land being a very limited resource. High levels of urban development on the 
island further exacerbate the situation as pressures for land development become more pronounced and economic issues relating to the cost of land arise. From a structural perspective, the fragmentation of agricultural land held within many small holdings means that human and physical resources are also spatially dispersed and thus difficult to manage. Finally the small size of the island and sector do not allow for many of the usual benefits associated with economy of scale to be derived (MESDC, 2018).

Operationally, management aspects relating to water efficiency and productivity are not implemented effectively (Attard et al., 2007). The widespread, and to a large extent unregulated abstraction for irrigation has placed a severe burden on the Maltese economy, due to the direct and indirect costs associated with its acquisition, distribution and application. Inefficiencies in water use stem mainly from losses (in storage and water conveyance) and irrigation design and implementation (low efficient application methods, problematic system setup, improper irrigation management practices) (Attard et al., 2007). Over-irrigation is a common problem, often due to lack of knowledge on the varied soil characteristics and crop water requirements across the islands (Hallett et al., 2017), and the lack of soil moisture monitoring to support operational decision-making (Attard et al., 2007).

Regarding economics and policy, Maltese agriculture has had to adapt to a different political landscape following its accession into the EU in 2004. Prior to this, the agricultural sector had been supported via a system of controls, price supports and import levies to secure farm incomes (Delia, 2005). However, after EU accession, levies on food imports were removed and the pressure for Maltese agriculture to become more competitive within the European marketplace increased significantly (MESDC, 2018). Moreover, the agricultural sector had to operate within the context of regulatory frameworks relating to environment, water and agriculture. Most current frameworks were established after Malta's accession and relate to implementation of EU regulations and incorporation of EU legislation into national laws. The latest regulatory framework, designed specifically for agriculture, is the National Agricultural Policy (NAP) for 2018-2028, which was prepared to support the sustainable development of the Maltese agricultural sector within EU frameworks and regulations such as the Common Agricultural Policy and Water Framework Directive (WFD, EC 2000).

Another economic factor that challenges the Maltese agricultural sector is the critical importance of the tourism sector for the local economy. The average daily population of tourists was approximately 4,334 in 2013 (Malta National Statistics Office, 2014), meaning that on an annual basis tourist influx is more than three times the population of Malta. Moreover, the peak of tourist season is between July and August, which coincides with the period of peak irrigation demand, thus posing an extra stressor to the already high water demand on the island (MRA, 2013). Water consumption for the tourism sector is estimated to about $10 \%$ of total water consumption, with mean water consumption per tourist estimated to be 149 1/day (Borg, 2009). Although this is a reasonable value for daily consumption, considering the extent of Malta's water scarcity issues, the additional water demand due to tourist numbers in summer constitutes a considerable burden on the water supply system. Securing supplies for tourism is considered a priority as the failure to provide sufficient and high quality water supply would lead to reputational water-risks for Malta and potentially financial impacts on the country in the case of reducing future tourism.

Within a social context, the ageing demographics of the agricultural population strongly impact on its potential for entrepreneurship, innovation and investment. Formal education in agriculture, and systematic training and extension support, is rare as the majority of farmers $(90 \%)$ have only practical experience and lack formal education in agriculture. Furthermore, since agriculture is predominantly based around family farm units, the skills, knowledge, land and related capital are mostly available only to the younger generation of families, meaning it is difficult for people coming into the sector to become involved and/or to invest (MESDC, 2018).

\section{Methodology}

\section{Drivers-Pressures-State-Impact-Response (DPSIR) framework}

The DPSIR framework was originally developed by the European Environment Agency (EEA) to represent the indicators that govern interactions between society and the environment in an integrated manner (Kristensen, 2004; Tscherning et al., 2012). A brief description of the framework components 
is given in Table 2. The DPSIR framework was used in this work to systematically organise the evidence emerging from the synthesis of literature, with the intention to better understand the interrelated issues that make Malta's agricultural sector vulnerable to water threats and to identify the specific elements that need to be addressed.

\section{Sustainability pillars}

The widely adopted "three pillars" framework for sustainability (Thwink, 2018) was used for defining and encapsuling "sustainability" within the strategy. This approach offered a powerful tool for defining the problem, by describing sustainability as the perfect alignment of all three pillars: economic, social and environmental (Figure 1). We considered the manner in which the three pillars of sustainability exert an impact upon, and influence the agricultural sector at three specific "scales" of operation, namely (i) farm level - including smallholdings and individual cadastral units; (ii) industry or sector level - collective decision-making and behaviours for the agricultural sector as a whole, and (iii) R\&D level - representing the responses needed by the academic and research community, including the requirement to support training and extension services for promoting the uptake and implementation of innovations and best management practices.

\section{Developing the strategy}

Drawing on published evidence and expert judgment from key informants in the agricultural sector, two fundamental aims were defined for each sustainability pillar. The strategic actions required to achieve each aim were then defined, along with the relative scale of intervention necessary for each action, where F was used to denote action at Farm level, S at Sector level and R for R\&D level. After drafting the initial priority actions, a participatory stakeholder workshop was used to critique and refine the strategy. The workshop was organised in November 2018 in Malta to engage selected stakeholders in the process of co-design and strategy validation. The participants were representatives from farming (cooperative), research (MCAST academics) and government (Agriculture Directorate and Energy and Water Agency). The outcomes from the workshop were then used to refine and finalise the strategy.

\section{Results}

\section{Application of the DPSIR framework}

A schematic representation of the DPSIR framework is shown in Figure 2. The Maltese climate, landform and geography, the expansion of irrigated agriculture, EU accession, and development of tourism in line with population growth and agricultural demographics are all identified as key drivers that lead to a number of environmental (e.g. limited area for agriculture and increasing water demand) and economic (e.g. increased dependence on fertilisers, changing market conditions and food supplychain risks) pressures. Pressures affect a number of states, some of which are physical (e.g. soil, groundwater) and others social (e.g. rural livelihoods) and/or economic (e.g. sector investment). A number of impacts arise as a result of the pressures imposed on the system states (e.g. aquifer depletion, increased cost for food production, loss of income for the farmers). Based on the perception of impacts, relevant responses to mitigate their consequences are identified (e.g. abstraction reform, precision irrigation management). These form the basis for priority actions which are pertinent to the three sustainability pillars. There are a number of interesting linkages in Figure 2 worth brief consideration. Drivers for one category (environment, economy, society) create pressures with multiple characteristics. For example, societal drivers create environmental and economic pressures, whilst there are no identified societal pressures. Geography, tourism development and population growth are all drivers that lead to additional pressures. Most of the affected states and impacts relate to economic aspects. Considering the number of pressures that affect each state, the most vulnerable states are groundwater and the market-place, followed by soils and crops. The individual response that could alleviate the largest number of impacts is precision irrigation management. 


\section{Water strategy}

The aims that underpin the actions for each pillar are presented below. For the environment pillar, the aims are to minimise water losses and to reduce the environmental impacts associated with agricultural irrigation on groundwater and ecosystems. Minimising losses relates to leakages and system inefficiencies and improving irrigation practices to save water. Reducing of environmental impacts relates to lowering the use of "blue" water for irrigation through the promotion of alternative sources and implementing practices to protect groundwater quality. For the economic pillar, the aims identified focus on increasing crop productivity and maximising economic returns from blue water. These translate to measures to increase yield and quality of irrigated crops while mitigating waterrelated risks to cropping, so as to increase the value per unit of water used. The fundamental aims for the societal pillar are to secure livelihoods and to develop the rural economy that is dependent on agriculture. Although these relate to economic measures, they are focused on societal aspects such as addressing the development of the economy through securing jobs in the agricultural sector and thus protecting the livelihoods of those involved, whilst fostering the traditions and history relating to rural agriculture.

The aims of each pillar, together with the actions needed to achieve sustainability in irrigated agriculture are schematically presented in Figure 3. Actions relating to better management of water and soil resources and irrigation reflect on both the environmental and economic pillars and are fundamental for the successful implementation of the strategy. Novel actions that have been identified as priorities include the reduction of water and energy footprints in crop production and the establishment of a soil monitoring programme within the environmental pillar, the establishment of demonstration farms and extension services for farmers within the economic pillar, and the support of policies that promote "value adding" activities within the societal pillar. Regarding the scale of intervention, the analysis distinguishes research as being important for supporting many of the economy-focused actions. The societal pillar is dominated by sector-level actions (highlighting the need for stronger collaboration and networking between individual farms) and the environmental pillar represented by a mix of both sector and farm level interventions.

\section{Stakeholder feedback}

Overall, the workshop participants confirmed that the main issues had been identified and agreed with the priorities for action. During discussion, market conditions were identified as being a fundamentally important stressor shaping decisions and planning in the agricultural sector. It was highlighted that the population of Malta, apart from growing steadily is also changing in composition (as people from other countries are moving to Malta, especially linked to tourism). This is an issue that also affects market conditions on the island. According to the stakeholders, farmers should be more involved in decisions affecting agriculture and in all the steps of the decision-making process. In order to bridge the gap between policies and decisions taken at national level and their implementation at farm level, the need for a top-down approach, used to guide farmers was highlighted. Finally, the importance of management approaches (for water, nutrients and soil on-farm) to overcome the major challenges faced by the sector were emphasised.

Coordination between different sectors and good management were also highlighted as important factors in the strategy, reflecting on all three pillars. Demonstration farms were identified as fundamentally important to support farmers in adopting new practices. It was mentioned also that EU funding could help support sustainable irrigated agriculture, as economic incentives could guide farmers towards adopting more sustainable practices and technologies. The need for reforming policies to address the problem of land fragmentation was also highlighted. Finally, in the consultation phase, the issue of data gaps was discussed. Stakeholders agreed that data gaps on the volumes of water used for irrigation, crop water requirements and estimated economic outputs from agriculture pose significant barriers to future research and knowledge translation into the sector. 


\section{Discussion}

\section{Cross-cutting themes in water strategy}

In the developed water strategy, priorities for action are presented as being parallel in each sustainability pillar. However, there are also cross-cutting themes and linkages throughout the strategy. For example, an important cross-cutting theme relates to use of data used to increase the economic returns from irrigated agriculture. More specifically, the actions of water use metering and abstraction and soil monitoring could together provide a comprehensive collection of data that does not currently exist. This will be essential to support the economic pillar's actions for precision irrigation and matching of cropping mixes to agro-climate and soils. Combining the environmental and economic focus, crop specific data on yield and water requirements could then be used to more accurately quantify the value of water for agriculture and to support improved selection of crops, relating to minimising water risks for production and maximising profits. This information would then feed into the societal pillar to support actions for promoting "value adding" activities. Another important cross-cutting theme relates to the chain of actions needed so that water saving measures and alternative technologies and practices are implemented and encouraged. Reducing dependence on groundwater and using alternative sources of water for irrigation (environmental pillar) is strongly aligned with establishment of demonstration farms and extension services for farmers so that the potential for improved production through adoption of new technologies can be realised. That is an important part of implementation, as farmers need clear evidence to demonstrate that their incomes will not be threatened by alternative practices prior to implementation, especially if capital or infrastructural investment is required.

\section{Policy and strategy implementation}

To safeguard the implementation of the strategy there are some issues relating to policy measures and government actions that need to be addressed in parallel. Alternative sources for irrigation water (such as desalinised water and treated wastewater) need to be made available to farmers along with incentives to promote their wider uptake, to reduce existing pressures on groundwater resources. Abstracted volumes of groundwater need to be urgently reduced to protect the sustainability of groundwater and soil systems. Currently there exists only limited data on the nature and composition of agricultural abstraction including the locations and volumes used. All water use figures for this sector have typically been estimated and modelled based on varying sources (FAO, 2006; MEPA, 2011). However, widespread illegal groundwater abstraction is known to occur and is not captured in official agricultural records (Conrad and Cassar, 2014). Establishing an effective network for monitoring groundwater abstractions is thus considered essential to ensure that the limited resources are utilised in the most efficient and effective manner.

Apart from abstraction monitoring, more extensive and widespread environmental monitoring will be fundamental for collecting relevant data needed to inform future soil and water management decisions. This can be supported by incorporating the new capabilities given by technological developments into agricultural practice. The establishment of weather and soil moisture monitoring stations, use of high resolution geospatial big data provided by earth observation and remote sensing applications (such as soil moisture and indices relating to crop development), in combination with agri-informatics analytical techniques that could support, for example, real-time analysis of inputs, could all help farmers and those engaged in supporting the industry in better understanding agricultural needs and thus provide valuable information to support high-value crop production in a water scarce environment.

\section{Conclusions}

This paper describes a methodological framework used to produce a strategy to support agricultural and water resources sustainability in Malta. The priorities for action directly align with sustainable development principles and have a strong focus on promoting innovations in technology and 
management. The target audience for the strategy is wide. Firstly, it targets the research community to provide guidance on the areas or gaps in knowledge where research programmes to support improving water resources management in agriculture should be directed. Secondly, the strategy is directly relevant to those in the industry and supporting knowledge translation and extension services at farm level. It is important to recognise that the challenges facing the agricultural sector will need a multiscalar and multi-stakeholder approach that is collaborative in nature.

This strategy was developed taking into account the regulatory frameworks relevant to the Maltese agricultural sector. However, suggestions for new or modified regulatory policies were beyond the scope of this immediate exercise. The assurance of water of adequate quantity and quality to support irrigated cropping, especially under the pressures of increased climate variability and change, have been identified as major issues threatening the sustainability of agriculture, not just in Malta but in many Mediterranean islands. Due to the complex inter-dependencies and multiple stressors that agriculture faces, trade-offs between socio-economic growth, the environment and managing natural resources to avoid depletion will be required to support sustainable development of the sector. In this context, managing water resources better will be key to securing a viable future for the agricultural sector, in-line with mitigating the water-related risks. The strategy has direct relevance to other Mediterranean islands facing similar challenges regarding reconciling water scarcity with agricultural development.

\section{Acknowledgement}

The research described in this paper forms part of FOWARIM, a project funded under the EC H2020TWINN-2015 programme (ID 692162). The authors are grateful for the contributions from all participants who participated in the stakeholder workshop.

\section{References}

Aparicio, J., Tenza-Abril, A.J., Borg, M., Galea, J., Candela, L., 2019. Agricultural irrigation of vine crops from desalinated and brackish groundwater under an economic perspective. A case study in Sigggiewi, Malta. Sci. Total Environ. 650, 734-740. doi:10.1016/j.scitotenv.2018.09.059

Attard, G., Azzopardi, E., 2005. An overview of irrigation system performance on the island of Malta. Options Mediterr. Ser. B 166, 165-172.

Attard, G., Mangion, J., Micallef, P., 2007. Water Use Efficiency and Water Productivity in Malta. Options Mediterr. Ser. B 57, 153-162.

Charlton, W.A., Beeley, B.W., 1987. Land use change in Malta. Land use policy 4, 96-101. doi:10.1016/0264-8377(87)90043-3

Daliakopoulos, I.N., Tsanis, I.K., Koutroulis, A., Kourgialas, N.N., Varouchakis, A.E., Karatzas, G.P., Ritsema, C.J., 2016. The threat of soil salinity: A European scale review. Sci. Total Environ. 573, 727-739. doi:10.1016/j.scitotenv.2016.08.177

Delia, E.P., 2005. The economic relevance of agriculture for Malta's economy. Malta.

EC, 2000. DIRECTIVE 2000/60/EC OF THE EUROPEAN PARLIAMENT AND OF THE COUNCIL.

EJOLT, n.d. DPSIR [WWW Document]. URL http://www.ejolt.org/2013/02/dpsir/ (accessed 10.29.18).

Eslamian, S., Eslamian, F., 2017. Handbook of Drought and Water Scarcity: Principles of Droughts and Water Scarcity. Taylor \& Francis Group, New York.

Eurostat, 2012. Agricultural census in Malta [WWW Document]. URL

https://ec.europa.eu/eurostat/statistics-explained/index.php/Agricultural_census_in_Malta (accessed 9.24.18).

FAO, 2006. Malta Water Resources Review.

Friends of the Earth, M., 2017. The local vegetable and fruit supply chain in Malta.

Hallett, S.H., Sakrabani, R., Thompson, A.J., Deeks, L.K. and Knox, J.W. 2017 Improving soil and 
water management for agriculture: Insights and Innovation from Malta. Journal of Applied Research and Practice, MCAST, Malta. 40-59. ISSN 2523-0433. Accessed at http://mcast.edu.mt:8223/rfm/source/Research/Journal/MCAST_Journal_Nov_2017_web.pdf.

Jacob, D., Petersen, J., Eggert, B., Alias, A., Christensen, O.B., Bouwer, L.M., Braun, A., Colette, A., Déqué, M., Georgievski, G., Georgopoulou, E., Gobiet, A., Menut, L., Nikulin, G., Haensler, A., Hempelmann, N., Jones, C., Keuler, K., Kovats, S., Kröner, N., Kotlarski, S., Kriegsmann, A., Martin, E., van Meijgaard, E., Moseley, C., Pfeifer, S., Preuschmann, S., Radermacher, C., Radtke, K., Rechid, D., Rounsevell, M., Samuelsson, P., Somot, S., Soussana, J.F., Teichmann, C., Valentini, R., Vautard, R., Weber, B., Yiou, P., 2014. EURO-CORDEX: New high-resolution climate change projections for European impact research. Reg. Environ. Chang. 14, 563-578. doi:10.1007/s10113013-0499-2

Kristensen, P., 2004. The DPSIR framework, European Environment Agency.

MBB, 2014. Recommendations - National Water Management Plan By the Malta Business Bureau's EU LIFE + Investing in Water Project.

MEPA, 2011. The Water Catchment Management Plan for the Maltese Islands.

MESDC, 2018. National Agricultural Policy for the Maltese Islands 2018 -2028. Malta.

MRA, 2013. State of the art of water resources in Mediterranean islands, D.3.1.1 MediWat.

National Statistics Office, 2016. Agriculture and Fisheries 2014. Malta.

National Statistics Office, 2015. World Water Day 2015 : Water and Sustainable Development. Valleta, Malta.

National Statistics Office, 2012. Census of Agriculture 2010. Malta.

Roberts, L., Cremona, M., Knox, G.J., Scicluna, M., Bonello, M., Bugeja, S., Calleya, S., Camilleri, J., Dingli, P.C., White, J.C., Debono, G., Falzon, M.A., Frendo, M., Galea, M., Sammut, J., Tabone, J. V, Tabone, P., Vassallo, C., Vassallo, J., Zahra, J.F.X., 2015. Why Malta'S National Water Plan Requires an Analytical Policy Framework.

Smeets, E., Weterings, R., Bosch, P., Büchele, M., Gee, D., 1999. Environmental indicators :

Typology and overview, European Environment Agency.

Thwink, 2018. The Three Pillars of Sustainability [WWW Document]. Thwink. URL

http://www.thwink.org/sustain/glossary/ThreePillarsOfSustainability.htm

Tscherning, K., Helming, K., Krippner, B., Sieber, S., Paloma, S.G. y, 2012. Does research applying the DPSIR framework support decision making? Land use policy 29, 102-110.

doi:10.1016/J.LANDUSEPOL.2011.05.009

United Nations, 2017. United National Demographic Yearbook 2016, United Nations. New York. doi:10.3406/tiers.1960.1240

van Vuuren, D.P., Edmonds, J., Kainuma, M., Riahi, K., Thomson, A., Hibbard, K., Hurtt, G.C., Kram, T., Krey, V., Lamarque, J.F., Masui, T., Meinshausen, M., Nakicenovic, N., Smith, S.J., Rose, S.K., 2011. The representative concentration pathways: An overview. Clim. Change 109, 5-31. doi:10.1007/s10584-011-0148-z

Vautard, R., Gobiet, A., Sobolowski, S., Kjellström, E., Stegehuis, A., Watkiss, P., Mendlik, T., Landgren, O., Nikulin, G., Teichmann, C., Jacob, D., 2014. The European climate under a $2{ }^{\circ} \mathrm{C}$ global warming. Environ. Res. Lett. 9, 034006. doi:10.1088/1748-9326/9/3/034006

Viola, F., Sapiano, M., Schembri, M., Brincat, C., Lopez, A., Toscano, A., Diamadopoulos, E., Charalambous, B., Molle, B., Zoumadakis, M., Torrens, A., Gallinas, M., Teresa, M., 2014. The State of Water Resources in Major Mediterranean Islands. Water Resour. 41, 639-648.

Zdruli, P., 2014. Land resources of the Mediterranean: Status, pressures, trends and impacts on future regional development. L. Degrad. Dev. 25, 373-384. doi:10.1002/ldr.2150. 
Table 1 Estimated irrigated areas (ha), volumes of water applied $\left(000 \mathrm{~m}^{3}\right)$ and monetary output (M Euro) for selected irrigated crop categories.

\begin{tabular}{llllll}
\hline Crop sector & $\begin{array}{l}\text { Cultivated area } \\
\text { (ha) }\end{array}$ & $\begin{array}{l}\text { Irrigated area } \\
\text { (ha) }\end{array}$ & $\begin{array}{l}\text { Proportion } \\
\text { irrigated }(\%) * *\end{array}$ & $\begin{array}{l}\text { Irrigation } \\
\text { volume }\left(000 \mathrm{~m}^{3}\right) \\
* * *\end{array}$ & $\begin{array}{l}\text { Irrigated crop } \\
\text { output value }(\mathrm{M} \\
\text { EUR) }\end{array}$ \\
\hline Potatoes & 701 & 632 & $18 \%$ & 5,091 & 6.5 \\
Vegetables & 1,731 & 1,357 & $39 \%$ & 10,930 & 13.9 \\
Flowers and seeds & 87 & 65 & $2 \%$ & 524 & 0.7 \\
Kitchen gardens & 1,123 & 587 & $17 \%$ & 4,728 & 6.0 \\
$\begin{array}{l}\text { Fruit and berry } \\
\text { plantations }\end{array}$ & 372 & 228 & $7 \%$ & 1,837 & 2.3 \\
$\begin{array}{l}\text { Citrus plantations } \\
\text { Olive plantations }\end{array}$ & 111 & 140 & $3 \%$ & 830 & 1.1 \\
Vineyards & 614 & 94 & $3 \%$ & 757 & 1.0 \\
\hline
\end{tabular}

* National Statistics Office (2012)

** Irrigated area per crop/Total irrigated area

*** Fraction of total irrigated area*Total irrigation volume $\left(28,176,000 \mathrm{~m}^{3}\right.$, National Statistics Office (2012))

**** (Irrigated area per crop/Total agricultural area)*Gross Agricultural Product

Total agricultural area: 12940 ha, National Statistics Office (2012)

Gross Agricultural Product: 133 million Euro (National Statistics Office, 2016)

Table 2 Description of DPSIR framework components (EJOLT, n.d.; Smeets et al., 1999; Kristensen, 2004).

\begin{tabular}{|l|l|}
\hline Drivers & $\begin{array}{l}\text { Environmental phenomena and processes, anthropogenic activities, socio-economic } \\
\text { and institutional developments that can cause environmental effects }\end{array}$ \\
\hline Pressures & The direct effect of a driver, leading to an impact for the environment \\
\hline States & $\begin{array}{l}\text { The condition of the system under study (natural, socio-economic or combination), } \\
\text { assessed either quantitatively and/or quantitatively }\end{array}$ \\
\hline Impacts & Changes in environmental functions, caused by the changes in the state of system \\
\hline Responses & Actions to prevent, eliminate, compensate or reduce impacts \\
\hline
\end{tabular}


Figure 1 The three pillars of sustainability (adapted from Thwink, 2018).

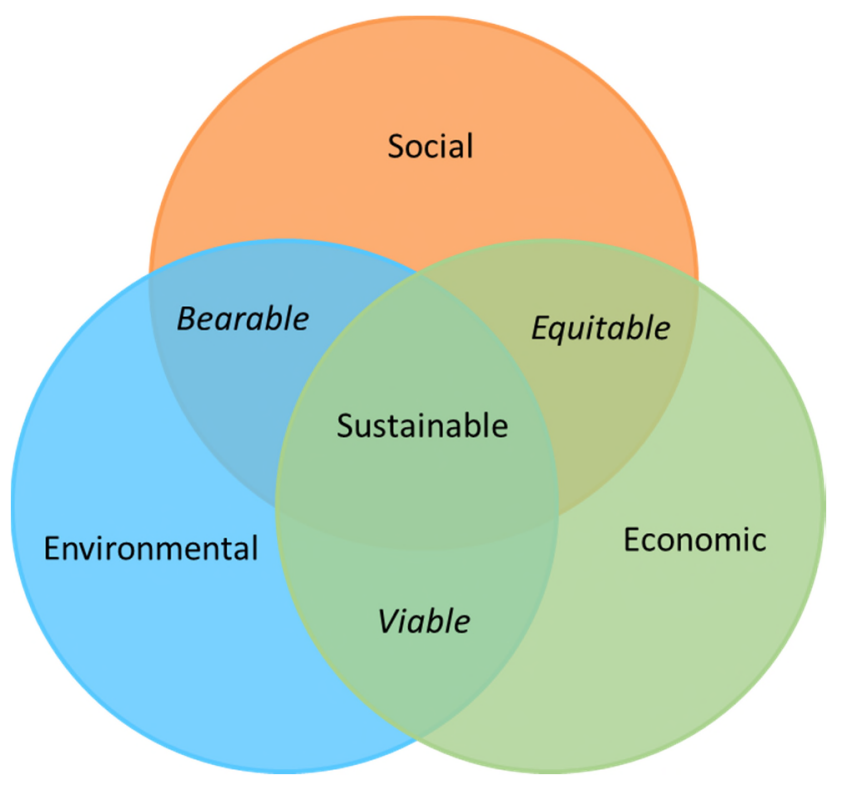


Figure 2 Schematic representation of the DPSIR framework for irrigated agriculture in Malta, with components identified according to their relevance to the sustainability pillars of environment, economy and society.

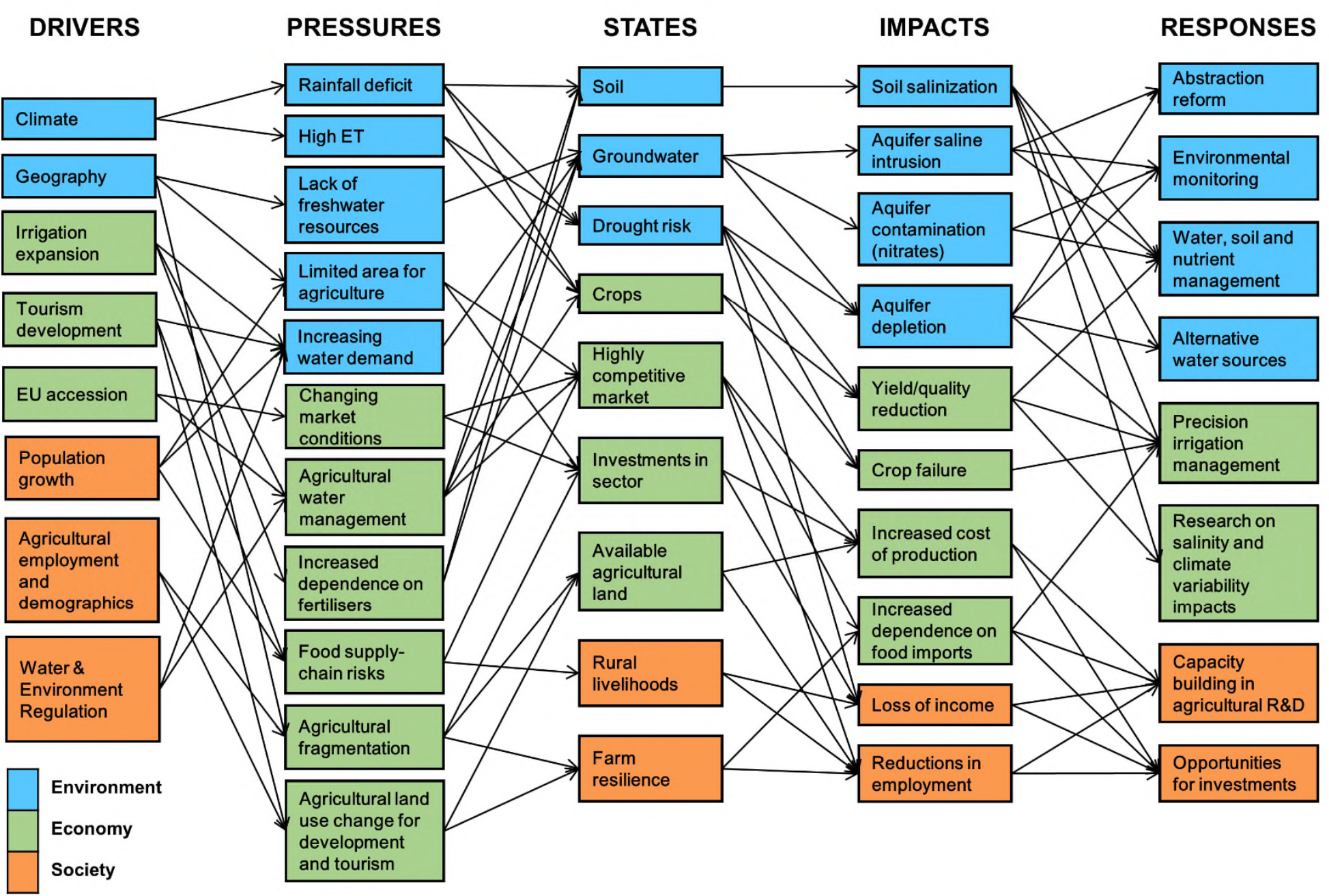


Figure 3 Priorities for action for achieving sustainable irrigated agriculture in Malta, aggregated by sustainability pillar.

\section{Environment}

\begin{tabular}{|c|c|}
\hline Minimise water losses & \\
\hline $\begin{array}{c}\text { Reduce the environmen } \\
\text { impacts of irrigation }\end{array}$ & \\
\hline $\begin{array}{l}\text { Minimise losses - Operation and } \\
\text { maintenance of irrigation and water } \\
\text { supply distribution networks }\end{array}$ & of त四 \\
\hline $\begin{array}{l}\text { Reduce dependence on groundwater } \\
\text { abstractions - Alternative sources of } \\
\text { water for irrigation (treated waste-water, } \\
\text { desalinisation, rainwater harvesting) }\end{array}$ & त- \\
\hline Irrigation scheduling and management & of \\
\hline $\begin{array}{l}\text { Nutrient and water management- } \\
\text { minimise nutrient leaching to aquifers }\end{array}$ & 踭 \\
\hline $\begin{array}{l}\text { Water use metering and abstraction } \\
\text { monitoring }\end{array}$ & 螬 \\
\hline $\begin{array}{l}\text { Lower water and energy footprints for } \\
\text { crop production }\end{array}$ & +人回 \\
\hline $\begin{array}{l}\text { Soil monitoring programme to provide } \\
\text { an environmental evidence base for } \\
\text { policy support }\end{array}$ & (임 \\
\hline
\end{tabular}

\section{Economy}

Increase crop productivity
Increase economic returns from
blue water

\section{Society}

\section{Secure rural livelihoods}

Develop the rural economy that is dependent on agriculture

\begin{tabular}{l}
$\begin{array}{l}\text { Improve opportunities for investments in } \\
\text { key sub-sectors }\end{array}$ \\
Support farmer networks and cooperation \\
$\begin{array}{l}\text { Promote niche cropping and distinctive } \\
\text { features of Maltese agriculture }\end{array}$ \\
$\begin{array}{l}\text { Raise awareness of the water challenges } \\
\text { facing the sustainability of agriculture in } \\
\text { Malta }\end{array}$ \\
$\begin{array}{l}\text { Reduce rural-urban migration } \\
\text { Creation of demonstration farms to } \\
\text { support farmer outreach and training }\end{array}$ \\
\hline $\begin{array}{l}\text { Support policies to promote 'value adding' } \\
\text { activities in primary production }\end{array}$ \\
\hline $\begin{array}{l}\text { Support on-farm diversification activities } \\
\text { (guesthouses, agro-tourism) }\end{array}$
\end{tabular}

